
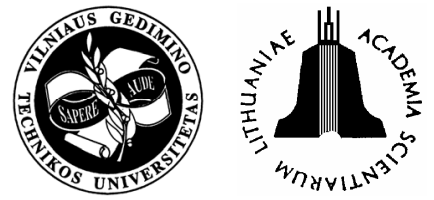

\title{
GENERAL MODEL OF ACCIDENT RATE GROWTH IN THE CONSTRUCTION INDUSTRY
}

\author{
Bozena Hola \\ Institute of Building Engineering, Wrocław University of Technology, \\ Wybrzeże Wyspiańskiego 27, 50-370 Wroctaw, Poland \\ E-mail: bozena.hola@pwr.wroc.pl \\ Received 18 Feb 2007; accepted 03 Aug 2007
}

\begin{abstract}
The accident level in sectors of the national economy is estimated from such data as: the number of persons employed in the analysed sector, the number of victims of accidents at work and the frequency and seriousness of the accidents. The data have a static character: they inform about the accident level in the analysed period but not about its variation over time. Also the pace of work contributes to accidents at work. The accident level and the production volume change over years. It is essential to be able to determine the rate of variation of two quantities. For this purpose a model enabling the assessment of dynamic changes in the investigated phenomena has been developed. Besides accident indices the model takes into account indices which measure the economic effects of construction production.
\end{abstract}

Keywords: accident rate, construction, accident indices, accident rate growth model.

\section{Introduction}

In most countries, the construction industry is one of the most dangerous industries [1-6].

Accidents at work result from the activation of the hazards associated with the work environment's technical, organisational and social conditions $[7,8]$. The accident situation in the construction industry is to a great extent determined by the specificity of this form of human activity which has many features conducive to accidents such as: work on different construction sites, work conditions differing between sites, subcontracting, a wide range of construction processes, a large number of machines and devices posing different hazards, the seasonal character of construction work and the effect of atmospheric conditions on the work environment [4, 5, 9-12].

The accident level in the particular sectors of the national economy, including the construction industry, is estimated by such data: the number of persons employed in the analysed sector, the number of victims of accidents at work and the number of days of disablement, as a result of accident at work. Two kinds of indicators, ie the number of accidents and the accident index (defined as the number of accidents per 100000 working persons), are used in studies by the Statistical Office of the European Communities (Eurostat) [13]. In Poland the number of accidents, the accident rate index, the accident seriousness index and the accident absenteeism index are used for statistical purposes [14]. None of the above indicators provides any information about the achieved values of production indices. Also the pace of work significantly contributes to accidents at work [15]. It is proposed here to take production indices, eg productivity and production value, into account in accident level assessments.
The accident indices used so far in both the EU and Poland have a static character [10, 16-19], ie they indicate the level of the phenomenon in an investigated period but do not provide any information about the rate of its changes [15]. It seems that indicators showing the accident situation in a dynamic way, eg chain indices of accident rate dynamics, should also be used to assess the accident situation. Dynamic accident rate indicators show the level of the phenomenon in the investigated period relative to its level in the preceding period. Thanks to such an analysis both negative and positive changes in the accident rate in short periods of time can be discerned.

Accident rate assessments perform an informational and motivational role. From the values of accident indices one can infer, among others, the specific character and level of the hazards associated with construction work, the effectiveness of the preventive measures, the competence of the management and inspection personnel in work safety management, the qualifications and motivation of workers for performing assigned tasks in a safe way, and the efficiency of the factory safety system and the national work protection system [3, 19-24]. The information is first of all the basis for taking decisions concerning preventive measures aimed at improving work safety.

By observing the development of the accident situation over time one can build its time series. A time series is a sequence of an investigated phenomenon's quantities observed in consecutive time units [25, 26]. By analysing time series one can estimate the trend function which in turn can be used to make a forecast of the investigated phenomenon in the next periods. 
The paper presents an in-depth analysis and assessment of the accident situation in the Polish construction industry in the years 1992-2005. A general model of accident rate growth for both static and dynamic indices, based on the analyses of the statistical data published by the Chief Statistical Office, has been built [14].

\section{Approach to accident rate assessment}

\subsection{Accident rate as static phenomenon}

The following indices were used to assess the static phenomenon:

- the total, minor, serious and fatal accident rate index,

- the accident seriousness index,

- the index of the accident rate per unit construction production.

The accident rate index specifies the number of victims of accidents at work in analysed year $t_{i}$, per each 1000 employed persons, and it is expressed by the following relation (1):

$$
w_{i, j, 1000}=\frac{l w_{i, j}}{l z_{i}} 1000, \text { at: } i=1, \ldots, n ; j=1, \ldots, 4,
$$

where: $l w_{i, j}$ - the number of victims of accidents at work in construction in year $t_{i}$, where:

$j=1-$ the total number of accidents,

$j=2-$ the number of minor accidents,

$j=3-$ the number of serious accidents,

$j=4-$ the number of fatal accidents,

$l z_{i}$ - the number of persons employed in construction in year $t_{i}$.

The accident seriousness index specifies the average number of working days lost due to sick leave per person injured in minor and serious accidents and expressed by the relation:

$$
c w_{i}=\frac{\sum_{j=2}^{3} d s_{i, j}}{\sum_{j=2}^{3} l w_{i, j}}, \text { at } i=1, \ldots, n ; j=2,3,
$$

where: $d s_{i, j}$ - the number of working days lost due to sick leave, $i=1, \ldots, n ; j=2,3$.

Construction production can be increased through the introduction of organisational changes into the work system, such as increasing the worktime and the workload, bringing additional process material components, eg technical means and work objects, onto the construction site and increasing the employment. All such changes lead to increased hazards on the construction site and thus to a greater probability of accidents at work.

It is proposed here to take into account, besides the number of employed and the number of victims, the value of production when evaluating the accident rate whereby one will be able to better assess the accident situation.

The index of the accident rate per unit construction production was calculated from the relation:

$$
w_{i, j / p}=\frac{w_{i, j, 1000}}{p_{i}}, \text { at: } i=1, \ldots, n: j=1, \ldots, 4,
$$

where: $p_{i}$ - the construction production value in year $t_{i}$ with the rate of inflation taken into account.

\subsection{Accident rate as dynamic phenomenon}

The following indices were used to assess the accident rate as a dynamic phenomenon:

- chain indices of accident rate and seriousness,

- chain indices of construction production value dynamics,

- an index of accident rate dynamics to construction production value dynamics.

A chain index of dynamics is a ratio of the level of a phenomenon in an investigated period to the level of the phenomenon in the preceding period [27]. From static variables $w_{i, j, 1000}, c w_{i}$ and $p_{i}$, new variables, ie chain indices of accident rate dynamics, a chain index of accident seriousness and a chain index of construction production value, were formed and expressed by the formula:

$$
\begin{gathered}
I w_{i, j, 1000}=\frac{w_{i, j, 1000}}{w_{i-1, j, 1000}}, \text { at: } i=1, \ldots, n ; j=1, \ldots, 4, \\
I c w_{i}=\frac{c w_{i}}{c w_{i-1}}, \quad \text { at: } i=1, \ldots, n, \\
I p_{i}=\frac{p_{i}}{p_{i-1}}, \quad \text { at: } i=1, \ldots, n,
\end{gathered}
$$

where: $I w_{i, j, 1000}$ - a chain index of accident rate dynamics, $I c w_{i}-$ a chain index of accident seriousness dynamics, $I p_{i}$ - a chain index of construction production dynamics.

In order to investigate the rate of variation in construction production versus the rate of variation in the frequency of accidents at work in construction, the following dynamic variation index was created:

$$
W(w / p)_{i, j}=\frac{I w_{i, j, 1000}}{I p_{i}}, \text { at: } i=1, \ldots, n ; j=1, \ldots, 4 .(7)
$$

\section{Description of mode}

For time interval $\left\langle t_{1}, \ldots \ldots, t_{n}\right\rangle$ covering the years 1992-2005 a model of accident trend in construction was built. The model includes both static and dynamic indices characterising the state of safety.

For each analysed time period $i$, where $i=1, \ldots, n$, observation vector $\left[t_{i}, l_{w i, j}, l_{z i}, p_{i}\right]$ was obtained. The information was used to calculate the accident indices from the above relations. In this way for each investigated phenomenon a sequence of values corresponding to the successive periods in the analysed time interval was obtained. The sequences form time series.

The accident related phenomena represented by a time series are the resultant of principal causes and random causes. Principal causes are reflected by the constant dependencies which occur in the investigated phenomenon. It is essential to identify the principlal causes in order to construct a trend model.

The presented trend model represents the permanent changes occurring in the level of the phenomenon and allows one to predict its level in the future. One should note, however, that in order for the forecast to be correct 
one must systematically check if no changes in the trend occur beyond the observed time interval. Such changes may apply to both the function's parameters and its analytical form. Since accidents are a negative phenomenon knowing the forecast one can take measures to reduce the predicted accident rate.

A general form of the trend function is expressed, according to $[25,28]$, by the formula:

$$
y_{k}=f(t)+u_{k} \text { at } k=1, \ldots, l,
$$

where: $k$ - the number of the explained variable, $y_{k}-$ the endogenous (explained) variable, $t$ - the exogenous (explanatory) variable, $f(t)$ - a hypothetical trend function, $u_{k}-$ a random component being a measure of the accidental deviation of variable $y_{k}$ from the trend line.

On the basis of previous investigations and analyses $[10,16,25]$ a trend function in the form of a polynomial of the $m$-th order was adopted as the general model of the accident rate trend, ie

$$
f_{k}(t)=\alpha_{0, k}+\alpha_{1, k} t^{1}+\ldots .+\alpha_{m, k} t^{m} ; \alpha_{m, k} \neq 0,
$$

where: $\alpha_{q, k}$ - parameters of the polynomial of the $m$-th order for the $k$-th explained variable, where: $q=0, \ldots, m$.

For $n$ observations of the vector of variables $t_{i}$ and $k$ vectors $Y_{k}, k=1, \ldots, l$, each of which contains $n$ observations of analyzed dynamic variable $y_{i, k}$, the trend model can be written in the matrix form:

$$
Y_{k}=T \mathrm{~A}_{k}+U_{k}
$$

where:

$$
\begin{gathered}
Y_{k}=\left[\begin{array}{c}
y_{1, k} \\
\ldots \\
y_{n, k}
\end{array}\right] T=\left[\begin{array}{ccccc}
1 & t_{1} & t_{1}^{2} & \ldots & t_{1}^{m} \\
\ldots & \ldots & \ldots & \ldots & \ldots \\
1 & t_{n} & t_{n}^{2} & \ldots & t_{n}^{m}
\end{array}\right] \\
\mathrm{A}_{k}=\left[\begin{array}{c}
\alpha_{0, k} \\
\ldots \\
\alpha_{m, k}
\end{array}\right] U_{k}=\left[\begin{array}{c}
u_{1, k} \\
\ldots \\
u_{n, k}
\end{array}\right], \text { where } k=1, \ldots, l
\end{gathered}
$$

for: $Y_{k}-$ a vector of $[n]$ observed values of explained variable $y_{i, k} ; T-$ a matrix of $[n, m+1]$ observed values of the time variable, $A_{k}-$ a vector of $[m+1]$ unknown pa-

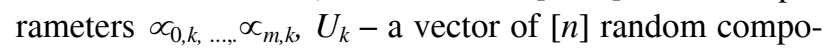
nents $u_{1, k}, \ldots, u_{n, k}$.

$$
\begin{aligned}
& y_{i, k}=w_{i, j, 1000} \text {, at: } k=1, \ldots, n ; j=1, \ldots, 4 . \\
& y_{i, k}=c w_{i}, \quad \text { at: } k=5 \text {. } \\
& y_{i, k}=w_{i, 1 / p} \text { at: } k=6, \ldots, 9 ; \quad j=1, \ldots, 4 \text {. } \\
& y_{i, k}=I w_{i, j, 1000}, \text { at: } k=10, \ldots, 13 ; j=1, \ldots, 4 \text {. } \\
& y_{i, k}=I c w_{i}, \text { at: } \mathrm{k}=14 \quad y_{i, k}=I p_{i} \text { at: } \mathrm{k}=15 \\
& y_{i, k}=W(w / p)_{i, 1} \text { at: } k=16, \ldots, 19 ; j=1, \ldots, 4 \text {. }
\end{aligned}
$$

For each $k=1, \ldots, l$, the trend function in the form of a polynomial of the $m$-th degree was determined.

Unknown parameters $\alpha_{q, k}$, at: $q=, . ., m$ of the trend function were estimated by the least squares method [25].
Polynomial degree $m$ was determined by comparing whether the remainder variances for the polynomial of $m$ and $m+1$.

A polynomial of the degree up from which the remainder variances did not change significantly was adopted as the trend function $[25,26]$.

\section{Model verification}

The coefficients of determination and correlation were adopted as the measure of the fit of the model to real values. The coefficient indicates what part of the general variability of characteristic $Y_{k}$ is described by the model. The determination coefficient is calculated from the formula:

$$
R_{k}^{2}=\frac{\mathrm{A}_{k}^{T}\left(T^{T} T\right)-n\left(\bar{y}_{k}\right)^{2}}{Y_{k}^{T} Y_{k}-n\left(\bar{y}_{k}\right)^{2}}, \quad k=1, \ldots, l,
$$

where: $n-$ the number of observations, $\bar{y}_{k}$ - the average of the terms of vector $Y_{k}$.

The correlation coefficient is expressed by the formula:

$$
R_{k}=\sqrt{R_{k}^{2}} .
$$

On the basis of $[25,26]$ it was assumed that if the correlation coefficient takes values from the interval:

- $0,00-0,33$, the correlation between characteristics $\mathrm{T}$ and $\mathrm{Y}$ is weak and insignificant and the model unsatisfactorily describes the investigated phenomenon;

- $0,34-0,66$, the correlation between the characteristics is medium and the model satisfactorily describes the investigated phenomenon;

- 0,67-0,90, the correlation between the characteristics is strong and the model well describes the investigated phenomenon;

- 0,91-1,00, the correlation between the characteristics is very strong and the model very well describes the investigated phenomenon.

\section{Investigation results and their analysis}

\subsection{Accident rate as statistical phenomenon}

\section{- Number of accidents at work}

Trend functions and determination and correlation coefficient values for the total number of accidents at work in the construction industry in the years 1992-2005 and for minor, serious and fatal accidents are shown in Table 1.

For the total number of accidents at work and minor and series accidents a 6th order polynomial very well models the investigated phenomenon. In each case the determination coefficient and the correlation coefficient reached values close to a unity, which is evidence of the trend function's very good fit to the empirical data. For the number of victims of fatal accidents at work in construction a 5 th order polynomial poorly describes the investigated phenomenon. The determination coefficient reached 0,6255 and the correlation coefficient reached 0,7908 . 
Table 1. Trend functions and determination and correlation coefficients for victims of accidents at work in construction in years 1992-2005

\begin{tabular}{|c|c|c|c|}
\hline No & $\begin{array}{l}\text { Investigated } \\
\text { phenomenon }\end{array}$ & Trend function & $\begin{array}{c}\text { Determination } \\
\text { and correlation } \\
\text { coefficients }\end{array}$ \\
\hline 1 & $\begin{array}{l}\text { Total num- } \\
\text { ber of vic- } \\
\text { tims of } \\
\text { accidents }\end{array}$ & $\begin{array}{r}f(t)=-0.0288 t^{6}+ \\
0.7654 t^{5}+1.6935 t^{4}- \\
204.86 t^{3}+1901.4 t^{2}- \\
5732.5 t+16839 \\
\end{array}$ & $\begin{array}{l}R_{k}^{2}=0.9885 \\
R_{k}=0.9942\end{array}$ \\
\hline 2 & $\begin{array}{l}\text { Number of } \\
\text { persons } \\
\text { injured in } \\
\text { minor acci- } \\
\text { dents at } \\
\text { work }\end{array}$ & $\begin{array}{c}f(t)=-0.0277 t^{6}+ \\
0.7258 t^{5}+1.931 t^{4}- \\
200.22 t^{3}+1833.3 t^{2}- \\
5406.6 t+15833\end{array}$ & $\begin{array}{c}R_{k}^{2}=0.989 \\
R_{k}=0.9944\end{array}$ \\
\hline 3 & $\begin{array}{l}\text { Number of } \\
\text { persons } \\
\text { injured in } \\
\text { serious } \\
\text { accidents }\end{array}$ & $\begin{array}{c}f(t)=-0.0021 t^{6}+ \\
0.0826 t^{5}-1.091 t^{4}+ \\
4.1568 t^{3}+20.892 t^{2}- \\
210.18 t+788.96\end{array}$ & $\begin{array}{r}R_{k}^{2}=0.9793 \\
R_{k}=0.9895\end{array}$ \\
\hline 4 & $\begin{array}{l}\text { Number of } \\
\text { victims of } \\
\text { fatal acci- } \\
\text { dents }\end{array}$ & $\begin{array}{c}f(t)=-0.001 t^{5}+ \\
0.1095 t^{4}-2.6222 t^{3}+ \\
23.061 t^{2}-75.416 t+ \\
195.17\end{array}$ & $\begin{array}{l}R_{k}^{2}=0.6255 \\
R_{k}=0.7908\end{array}$ \\
\hline
\end{tabular}

Fig 1 shows the variation in the number of victims of serious of accidents at work in construction in the years 1992-2005 while the variation of victims of fatal accidents in the same period is shown in respectively Fig 2. The number of persons injured in serious accidents at work in the construction industry in the investigated period shows a marked downward trend while the number of fatalities in accidents at work shows a variable downward-upward trend.

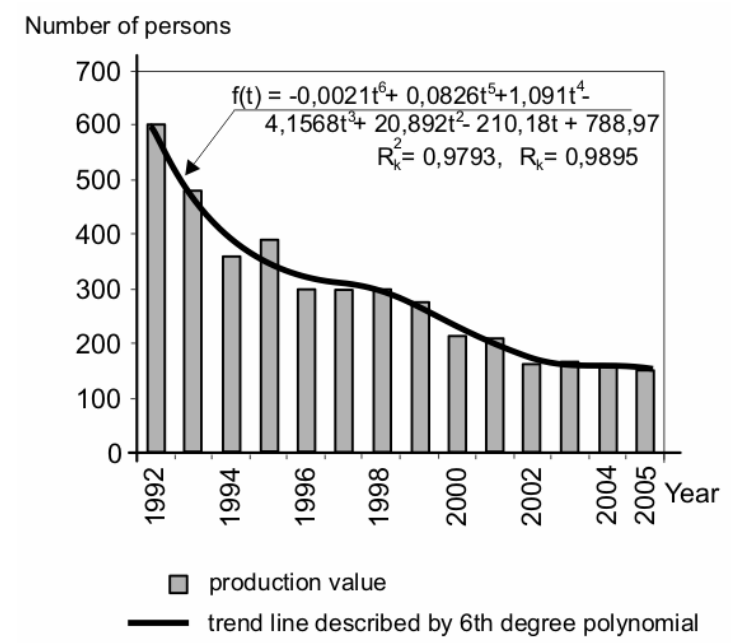

Fig 1. Number of persons injured in serious accidents at work in construction in 1992-2005

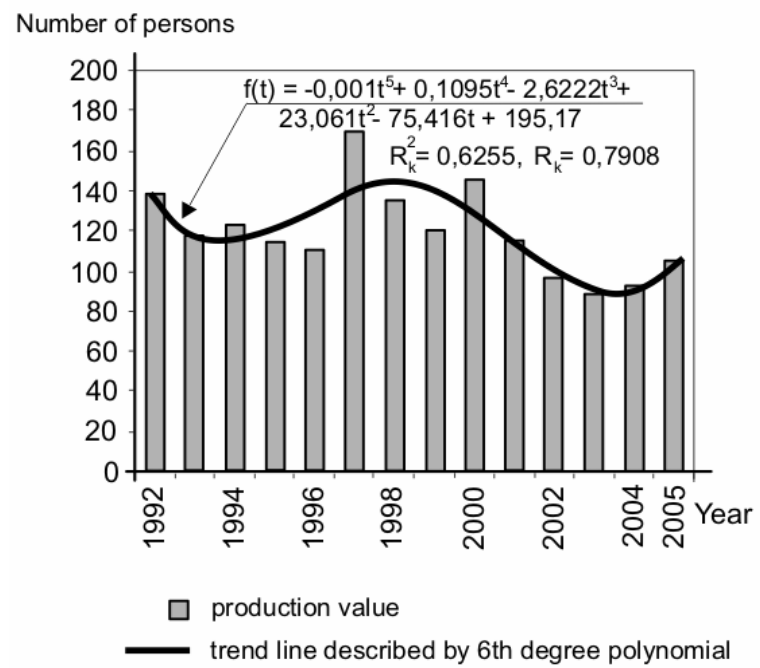

Fig 2. Number of victims of fatal accidents at work in construction in 1992-2005

The number of victims of accidents at work in the analysed period is not a fully reliable measure of the state of safety in the considered sector of national economy. From the histograms in Figs 1-2 one cannot conclude how often the employed persons meet with accidents, how serious the accidents are and what effect on the accident rate the production rate has. For comparing and rating the particular sectors of national economy with regard to the accident situation, the accident rate index and the accident seriousness index are helpful [10, 17].

\section{- $\quad$ Rate and seriousness of accidents}

Trend functions and determination and correlation coefficient values for the accident rate index and the accident seriousness index are shown in Table 2.

Table 2. Trend functions and determination and correlation coefficients for indices of rate and seriousness of accidents at work in construction in years 1992-2005

\begin{tabular}{|c|c|c|c|}
\hline No & $\begin{array}{l}\text { Investigated } \\
\text { phenomenon }\end{array}$ & Trend function & $\begin{array}{c}\text { Determination } \\
\text { and correlation } \\
\text { coefficients } \\
\end{array}$ \\
\hline 1 & $\begin{array}{l}\text { Total acci- } \\
\text { dent rate } \\
\text { index }\end{array}$ & $\begin{array}{c}f(t)=0.0158 \mathrm{t}^{3}- \\
0.3851 t^{2}+2.4922 t+ \\
9.8696\end{array}$ & $\begin{array}{c}R_{k}^{2}=0.8026 \\
R_{k}=0.8958\end{array}$ \\
\hline 2 & $\begin{array}{l}\text { Minor acci- } \\
\text { dent rate } \\
\text { index }\end{array}$ & $\begin{array}{c}f(t)=0.0155 t^{3}- \\
0.3828 t^{2}+2.537 t+ \\
9.1049\end{array}$ & $\begin{aligned} R_{k}^{2} & =0.8065 \\
R_{k} & =0.8980\end{aligned}$ \\
\hline 3 & $\begin{array}{l}\text { Serious } \\
\text { accident rate } \\
\text { index }\end{array}$ & $\begin{array}{c}f(t)=4 \mathrm{E}-05 t^{3}+ \\
0.0027 t^{2}-0.0722 t+ \\
0.6604\end{array}$ & $\begin{array}{l}R_{k}^{2}=0.9459 \\
R_{k}=0.9725\end{array}$ \\
\hline 4 & $\begin{array}{l}\text { Fatal acci- } \\
\text { dent rate } \\
\text { index }\end{array}$ & $\begin{array}{c}f(t)=4 \mathrm{E}-08 t^{6}+ \\
4 \mathrm{E}-06 t^{5}-0.0001 t^{4}+ \\
0.0013 t^{3}-0.0043 t^{2}+ \\
0.006 t+0.133\end{array}$ & $\begin{array}{l}R_{k}^{2}=0.5955 \\
R_{k}=0.7716\end{array}$ \\
\hline 6 & $\begin{array}{l}\text { Accident } \\
\text { seriousness } \\
\text { index }\end{array}$ & $f(t)=0.967 t+44.24$ & $\begin{array}{c}R_{k}^{2}=0.9347 \\
R_{k}=9667\end{array}$ \\
\hline
\end{tabular}


For the total accident rate index and the minor accident rate index, the trend is well described by the trend function circumscribed by a 3rd degree polynomial. In both cases the determination coefficient exceeded 0.8 which means that in over $80 \%$ this function explains the variation of the analyzed variable, and the correlation coefficient exceeded 0.89 . In case of the serious accident rate index, the trend function described by the 3rd degree polynomial describes well the variation of the analysed variable. The determination coefficient reached 0.9459 , while the correlation coefficient reached 0.9725 The fatal accident rate index is well described by the 6th degree polynomial. The determination coefficient reached 0.5955 while the correlation coefficient amounted to 0.7716 . The accident seriousness index is very well described by the linear function. The function in $93 \%$ explains the variation of this index. The accident seriousness index is very well described by a 1 st degree polynomial. The determination coefficient reached 0.9347 while the correlation coefficient reached 0.9667 .

The variation of the total work accident rate index per 1000 persons employed in the construction industry in the years 1992-2005 is illustrated in Fig 3.

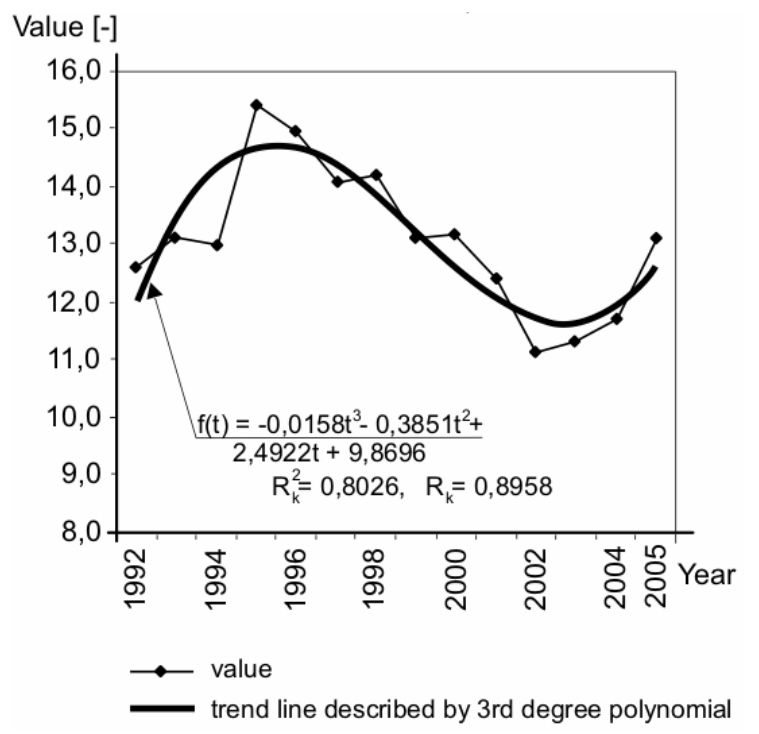

Fig 3. Total accident rate index 1992-2005

In the analysed time interval the variation of this index shows an upward-downward-upward trend. The index reached its peak in 1995 and its minimum in 2003. In the last two years of the period the value of this index increases. The variation in the index of the rate of fatal accidents per each 1000 persons employed in construction is illustrated in Fig 4.

In the analyzed period the variation of this index shows an upward-downward-upward trend. The fact that this index significantly increases in the last two years of the analyzed period is highly alarming.

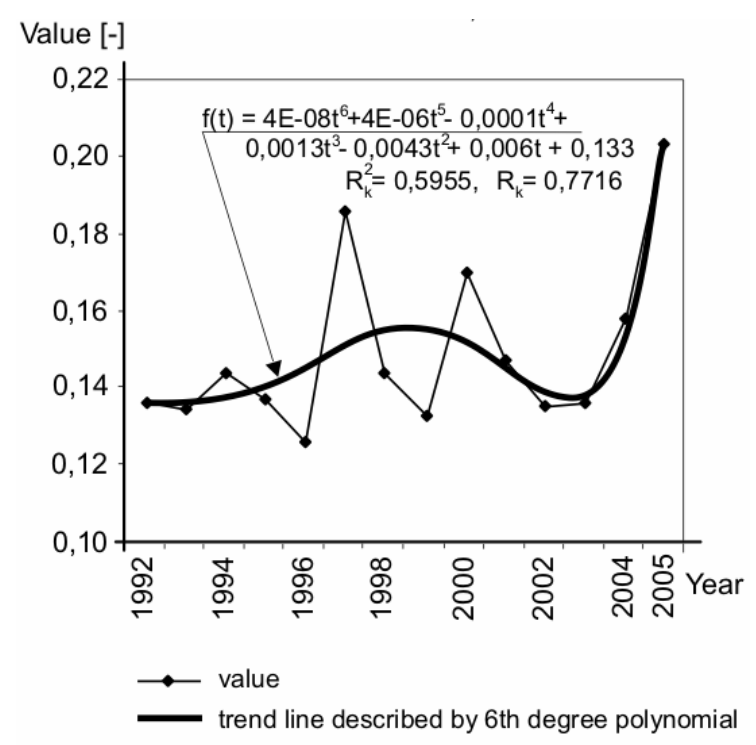

Fig 4. Index of rate of fatal accidents per 1000 persons employed in construction in 1992-2005

\section{- Accident rate relative to construction production value of 1 M PLN}

Table 3 shows trend functions and determination and correlation coefficients for the accident rate indices relative to the construction production value of $1 \mathrm{M}$ PLN.

The trend function described by a 2 nd degree polynomial very well describes the trend of the total accident rate index. The trend function described by a 3rd degree polynomial very well describes the minor, serious and fatal accident rate indices. In each of the investigated phenomena the determination coefficient and the correlation coefficient reached a value close to a unity.

Table 3. Trend functions and determination and correlation coefficients for construction work accident rates per construction production value of $1 \mathrm{M}$ PLN in 19922005

\begin{tabular}{l|l|c|c}
\hline No & $\begin{array}{c}\text { Investigated phe- } \\
\text { nomenon }\end{array}$ & Trend function & $\begin{array}{c}\text { Determina- } \\
\text { tion and } \\
\text { correlation } \\
\text { coefficients }\end{array}$ \\
\hline 1 & $\begin{array}{l}\text { Total accident rate } \\
\text { index per construc- } \\
\text { tion production } \\
\text { value of 1M }\end{array}$ & $\begin{array}{c}f(t)=0.005 t^{2}- \\
0.1162 t+0.7771\end{array}$ & $\begin{array}{c}R_{k}^{2}= \\
0.9905\end{array}$ \\
\hline 2 & $\begin{array}{l}\text { Minor accident rate } \\
\text { index per construc- } \\
\text { tion production } \\
\text { value of 1M }\end{array}$ & $\begin{array}{c}f(t)=9 \mathrm{E}-05 t^{3}+ \\
0.0027 t^{2}-0.0958 t+\end{array}$ & $\begin{array}{c}R_{k}^{2}= \\
0.7159\end{array}$ \\
\hline 3 & $\begin{array}{l}\text { Serious accident } \\
\text { rate index per con- } \\
\text { struction production } \\
\text { value of 1M }\end{array}$ & $\begin{array}{c}0.0103 t+0.04 \\
R_{k}=0.9949\end{array}$ & $\begin{array}{c}R_{k}^{2}= \\
0.9933 \\
R_{k}=0.9966\end{array}$ \\
\hline 4 & $\begin{array}{l}\text { Fatal accident rate } \\
\text { index per construc- } \\
\text { tion production } \\
\text { value of 1M }\end{array}$ & $f(t)=-4 \mathrm{E}-0 t^{3}+$ & $\begin{array}{l}R_{k}^{2}=0.9818 \\
R_{k}=0.9908\end{array}$ \\
\hline
\end{tabular}


The variation in the serious accident rate index relative to the construction production value of $1 \mathrm{M}$ PLN is illustrated in Fig 5. From the beginning of the analysed period to 2001 the index shows a very favourable downward trend, whereas in the next years it shows a slightly upward trend.

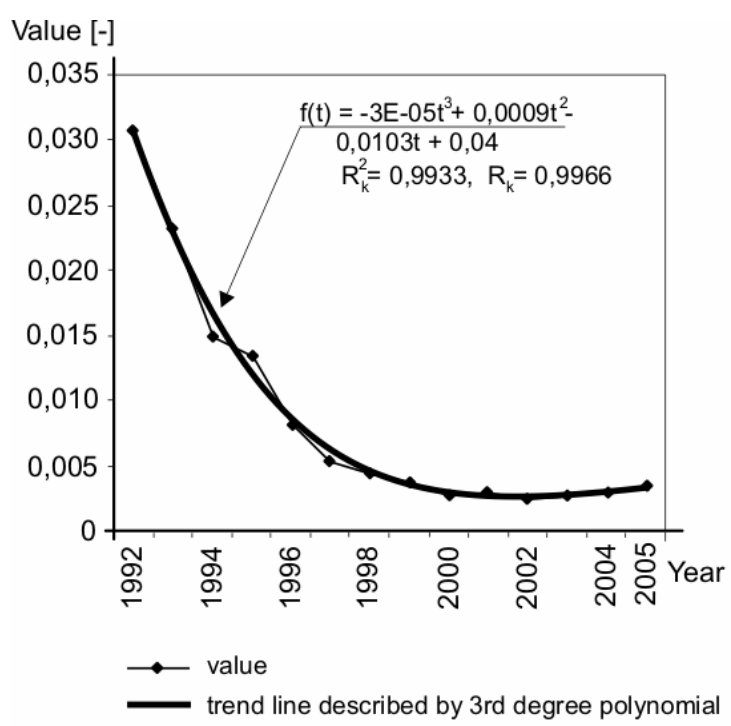

Fig 5. Serious accident rate index per construction production value of 1 M PLN in 1992-2005

Fig 6 illustrates the variation in the fatal accident rate index relative to the construction production value of 1 M PLN. This index also shows a downward upward trend. It reached its minimum in 2001, then it shows a distinctly upward trend.

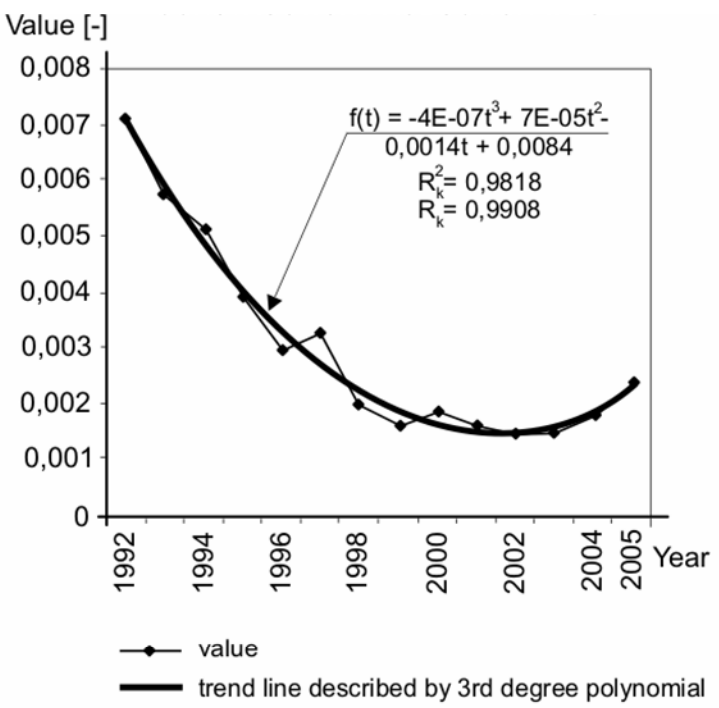

Fig 6. Fatal accident rate index per construction production value of $1 \mathrm{M}$ in 1992-2005

\subsection{Assessment of accident rate as dynamic phenomenon}

\section{- Chain indices of accident rate dynamics}

The values which the chain indices of accident rate dynamics reached in the preceding year were used as the reference for calculating the indices. If a chain index of accident rate dynamics $I \triangleright 1$, this means that an unfavourable increase of the analysed phenomenon occurred in the investigated period relative to the value reached in the preceding period. If a chain index of accident rate dynamics $I_{i} \leq 1$, this means that a favourable decrease of the analysed phenomenon occurred in the investigated period relative to its level in the preceding period or that the phenomenon remains at the same level.

Table 4 shows trend functions and determination coefficients for accident rate dynamics chain indices described by a 6th degree polynomial. The total accident rate dynamics index is satisfactorily described by the 6th degree polynomial. In the case of the total and minor work accident rate dynamics, the 6th order polynomial satisfactorily describes the variability of the investigated variables.

Table 4. Trend functions and determination and correlation coefficients for construction work accident rate dynamics indices in 1992-2005

\begin{tabular}{|c|c|c|c|}
\hline No & $\begin{array}{l}\text { Investigated } \\
\text { phenomenon }\end{array}$ & Trend function & $\begin{array}{c}\text { Determination } \\
\text { and correlation } \\
\text { coefficients }\end{array}$ \\
\hline 1 & $\begin{array}{l}\text { Total work } \\
\text { accident rate } \\
\text { dynamics per } \\
1000 \text { employed } \\
\text { persons }\end{array}$ & $\begin{array}{r}\quad f(t)=2 \mathrm{E}-06 t^{6}- \\
8 \mathrm{E}-0 t^{5}+0.0011 t^{4}- \\
0.00 t^{3}-0.0017 t^{2}+ \\
0.0843 t+0.9183\end{array}$ & $\begin{array}{l}R_{k}^{2}=0.4834 \\
R_{k}=0.7234\end{array}$ \\
\hline 2 & $\begin{array}{l}\text { Minor work } \\
\text { accident rate } \\
\text { dynamics per } \\
1000 \text { employed } \\
\text { persons }\end{array}$ & $\begin{array}{r}f(t)=6 \mathrm{E}-06 t^{6}-- \\
0.0003 t^{5}+0.007 t^{4}- \\
0.0709 t^{3}+0.3398 t^{2}- \\
0.6801 t+1.3962\end{array}$ & $\begin{array}{l}R_{k}^{2}=0.7177 \\
R_{k}=0.8471\end{array}$ \\
\hline 3 & $\begin{array}{l}\text { Serious work } \\
\text { accident rate } \\
\text { dynamics per } \\
1000 \text { employed } \\
\text { persons }\end{array}$ & \begin{tabular}{l}
\multicolumn{1}{c}{$f(t)=2 \mathrm{E}-06 t^{6}-$} \\
$0.0001 t^{5}+0.002 t^{4}-$ \\
$0.0272 t^{3}+0.1538 t^{2}-$ \\
$0.4066 t+1.2777$
\end{tabular} & $\begin{array}{l}R_{k}^{2}=0.2974 \\
R_{k}=0.5453\end{array}$ \\
\hline 4 & $\begin{array}{l}\text { Fatal work } \\
\text { accident rate } \\
\text { dynamics per } \\
1000 \text { employed } \\
\text { persons }\end{array}$ & $\begin{array}{l}f(t)=-3 \mathrm{E}-06 t^{6}+ \\
0.0001 t^{5}-0.0021 t^{4}+ \\
0.0138 t^{3}-0.0356 t^{2}+ \\
0.036 t+0.9867\end{array}$ & $\begin{array}{l}R_{k}^{2}=0.2441 \\
R_{k}=0.4940\end{array}$ \\
\hline
\end{tabular}

Figs 7-8 illustrate the variation in the chain indices of the total and fatal accident rate dynamics per each 1000 persons employed in the construction industry.

The trends of the phenomena are described by a linear function and a 6 th degree polynomial. None of the functions describes the trend of the phenomena with sufficient accuracy. The course of the trend line described by the linear function indicates a general upward or downward trend in 1992-2005. The course of the trend line described by the 6th degree polynomial indicates changing dynamics of the phenomena in the given time intervals. It is advantageous when the trend line slopes 
downwards since this indicates that the accident rates in the successive years of the analysed period are lower than the ones in the preceding years. It is disadvantageous when the trend line slopes upwards since this indicates that the accident rate increases.

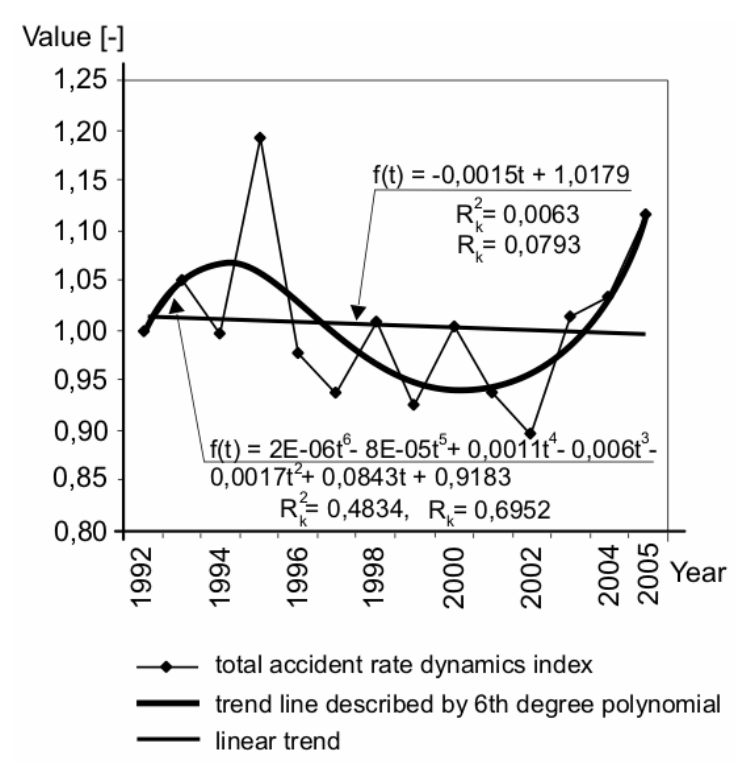

Fig 7. Total construction work accident rate dynamics in 1992-2005

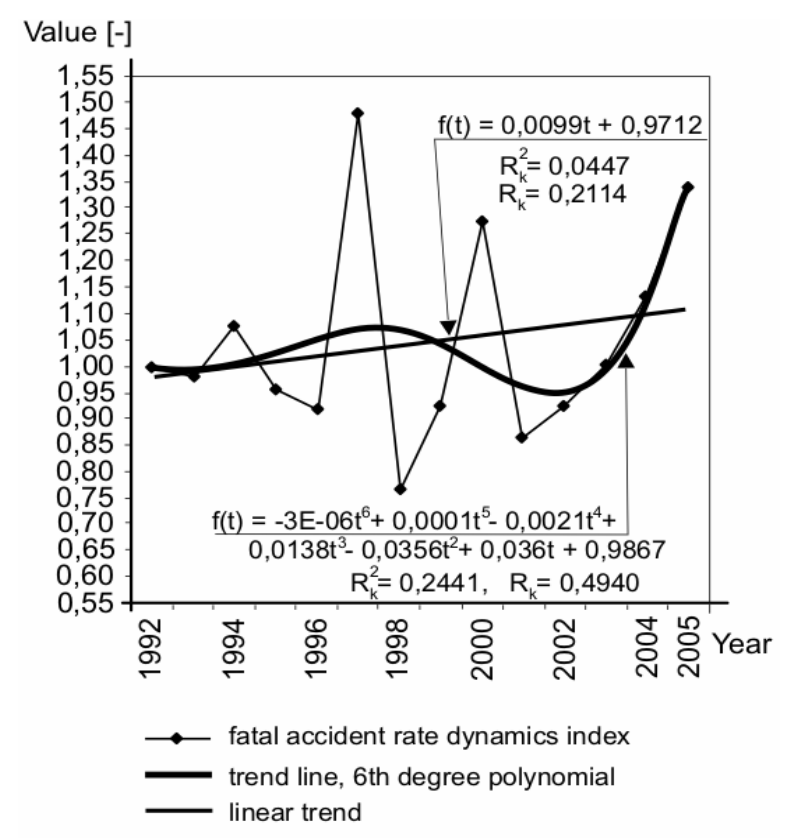

Fig 8. Dynamics of total fatal accident rate in construction in 1992-2005

In case of the total accident rate dynamics shown in Fig 7, the linear function explains very little the variation of the explained variable, indicating a general downward trend of the phenomenon. The trend line described by the 6th degree polynomial confirms the unfavourable upward dynamics of the accident rate up to 1995 , followed by its favourable decline from 1995 to 2002 and then again by a very unfavourable rise. The 6 th degree polynomial only in $52 \%$ explains the variation of the total accident rate dynamics in construction.

The graphs in Fig 8 illustrate fatal accident rate growth dynamics. This phenomenon is characterised by sharp changes in 1996-2001. In that period the dynamics of rises and falls in the fatal accident rate were the greatest. Since 2001 the fatal accident rate dynamics have been steadily increasing. The 6th degree polynomial only in $24 \%$ explains the variation in the fatal accident rate. According to the trend line described by the linear function the phenomenon shows un upward tendency.

Figs 7-8 show that the chain indices of accident rate dynamics are very sensitive to any changes in neighbouring periods. For example, in 1997 the chain index of fatal accident rate dynamics reach 1.479 . This means that the frequency of fatal accidents increased by $47.9 \%$ relative to the preceding year. Whenever so high unfavourable values of dynamics indices are recorded the causes of the situation should be identified and preventive measures should be taken.

\section{- Construction production value dynamics in relation to accident rate dynamics}

Table 5 shows trend functions and determination and correlation coefficients for the chain index of construction production value dynamics and the construction production value dynamics indices in relation to the rate of accidents at work in the construction industry in 1992-2005.

The variation in the chain index of construction production value dynamics is very well described by the 6th degree polynomial. The determination coefficient reached 0.9350 . The variation in the indices of total, minor, serious and fatal accident rate dynamics relative to construction production value dynamics is described with a sufficient accuracy by the 6th degree polynomial. The determination coefficient reached respectively 0.6238 , $0.6136,0.6779$ and 0.5488 . The correlation coefficient reached respectively $0.8917,0.7833,0.8233$ and 0.7408 .

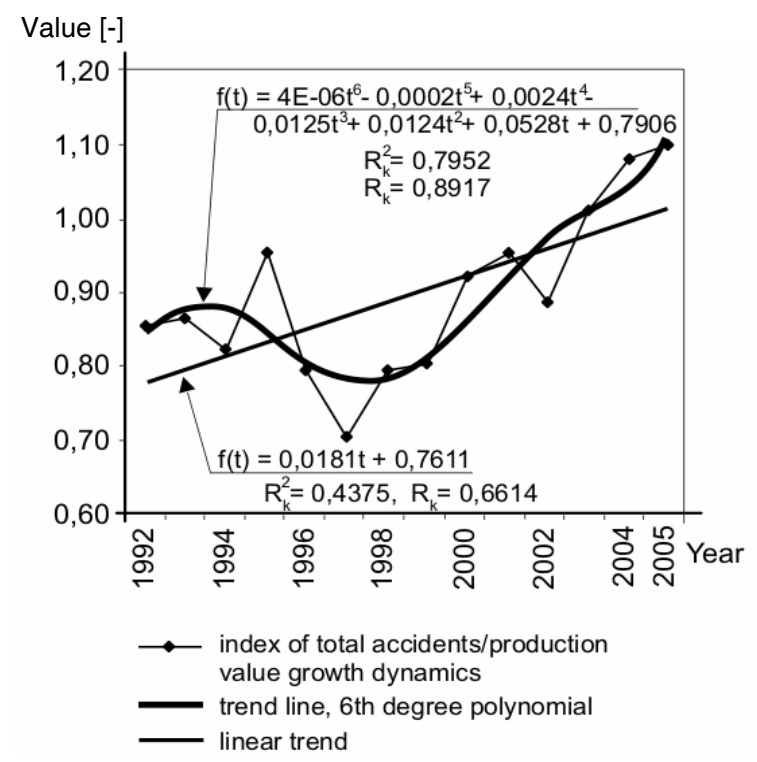

Fig 9. Total accident rate dynamics to construction production value dynamics in 1992-2005 
Figs 9-11 illustrate the indices of total, serious and fatal accident rate dynamics in relation to the construction production value dynamics. The declining trend line means that the growth rate of the construction production value is higher than that of the accident rate. This is of course advantageous. The sloping upwards trend line means that the rate of growth of the construction production value is lower than that of the accident rate, which is disadvantageous.

Table 5. Trend functions and determination and correlation coefficients for construction production dynamics indices relative to the rate of accidents at work in construction in 1992-2005

\begin{tabular}{|c|c|c|c|}
\hline No. & $\begin{array}{l}\text { Investigated } \\
\text { phenomenon }\end{array}$ & Trend function & $\begin{array}{c}\text { Determination } \\
\text { and correlation } \\
\text { coefficients }\end{array}$ \\
\hline 1 & $\begin{array}{l}\text { Chain index of } \\
\text { construction } \\
\text { production } \\
\text { value dynam- } \\
\text { ics }\end{array}$ & $\begin{array}{c}f(t)=-6 \mathrm{E}-06 t^{6}+ \\
0.0002 t^{5}-0.0032 t^{4}+ \\
0.0193 t^{3}-0.0486 t^{2}+ \\
0.0669 t+1.1436\end{array}$ & $\begin{array}{l}R_{k}^{2}=0.935 \\
R_{k}=09669\end{array}$ \\
\hline 2 & $\begin{array}{l}\text { Index of total } \\
\text { accident rate } \\
\text { dynamics to } \\
\text { construction } \\
\text { production } \\
\text { value dynam- } \\
\text { ics }\end{array}$ & $\begin{array}{c}f(t)=4 \mathrm{E}-06 t^{6}- \\
0.0002 t^{5}+0.0024 t^{4}- \\
0.0125 t^{3}+0.0124 \mathrm{t}^{2}+ \\
0.0528 t+0.7906\end{array}$ & $\begin{array}{l}R_{k}^{2}=0.7952 \\
R_{k}=0.8917\end{array}$ \\
\hline 3 & $\begin{array}{l}\text { Index of minor } \\
\text { accident rate } \\
\text { dynamics to } \\
\text { construction } \\
\text { production } \\
\text { value dynam- } \\
\text { ics }\end{array}$ & $\begin{array}{c}f(t)=-1 \mathrm{E}-05 t^{6}+ \\
0.0006 t^{5}-0.0118 t^{4}+ \\
0.106 t^{3}-0.468 t^{2}+ \\
0.9167 t+0.6449\end{array}$ & $\begin{array}{l}R_{k}^{2}=0.6136 \\
R_{k}=0.7833\end{array}$ \\
\hline 4 & $\begin{array}{l}\text { Index of seri- } \\
\text { ous accident } \\
\text { rate dynamics } \\
\text { to construction } \\
\text { production } \\
\text { value dynam- } \\
\text { ics }\end{array}$ & $\begin{array}{r}f(t)=6 \mathrm{E}-06 t^{6}- \\
0.0003 t^{5}+0.0044 t^{4}- \\
0.0377 t^{3}+0.1717 t^{2}- \\
0.4078 t+1.1192\end{array}$ & $\begin{array}{l}R_{k}^{2}=0.6779 \\
R_{k}=0.8233\end{array}$ \\
\hline 5 & $\begin{array}{l}\text { Fatal accident } \\
\text { rate dynamics } \\
\text { to construction } \\
\text { production } \\
\text { value dynam- } \\
\text { ics }\end{array}$ & $\begin{array}{c}f(t)=-5 \mathrm{E}-07 t^{6}+ \\
5 \mathrm{E}-05 t^{5}-0.0012 t^{4}+ \\
0.0125 t^{3}-0.0573 t^{2}+ \\
0.09 t+0.7922\end{array}$ & $\begin{array}{l}R_{k}^{2}=0.5488 \\
R_{k}=0.7408\end{array}$ \\
\hline
\end{tabular}

The trend lines described by the 6th degree polynomial indicate unfavourable upward tendencies in some time intervals and favourable downward tendencies in the other time intervals. Despite the variable tendencies of the accident rate growth index relative to the growth of construction production, the general trends in the analysed period are not favourable. The lines in the form of linear functions show upward trends for all the above phenomena. This is highly alarming since the average increments in the rate of accidents per each 1000 persons employed in construction were larger than the average increments in the construction production value.

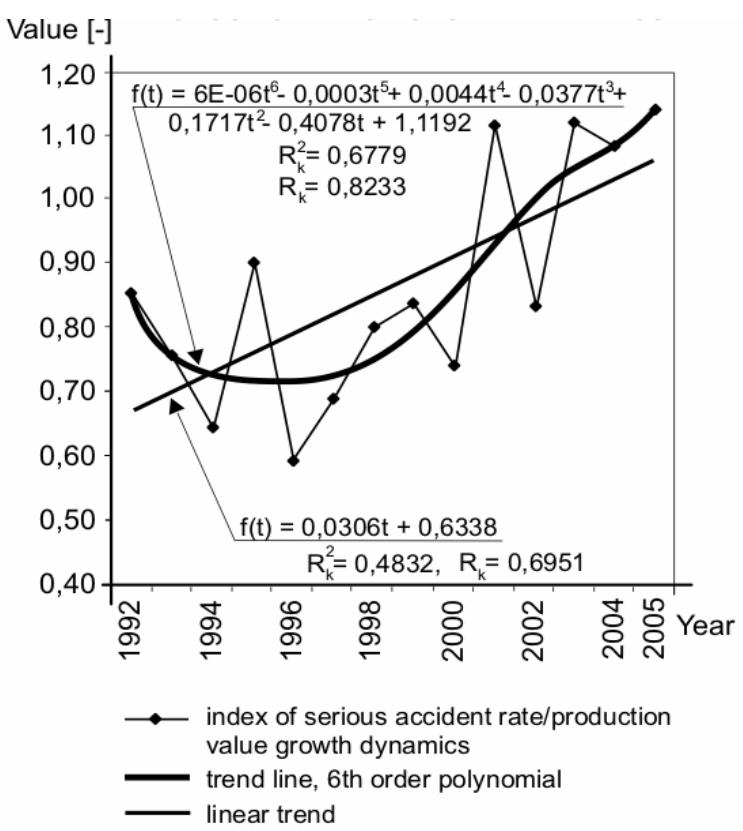

Fig 10. Index of serious accidents rate dynamics relative to construction production value dynamics construction industry in 1992-2005

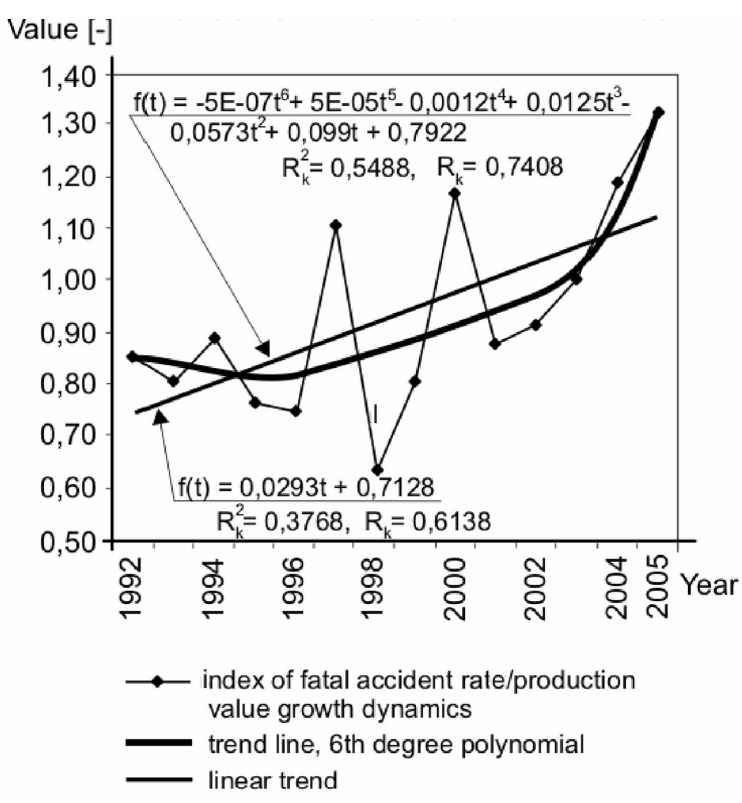

Fig 11. Index of fatal accident rate dynamics relative to construction production value dynamics in construction industry in 1992-2005

\section{Conclusions}

1. So far the accident rate in the construction industry has been estimated from such data as: the number of employed persons, the number of victims of accidents at work and the accident rate and seriousness indices. The above indicators have a static character: they inform us about the level of the investigated phenomenon in successive periods but do not give any information about the dynamics of its changes in the successive periods. Also the intensity of work has a bearing on accidents at work. In order to gain a fuller picture of the changes in the state 
of safety in the construction industry in an investigated time interval, one should take into account the production indices such as the construction production value.

2. For the evaluation of dynamic changes one can use the growth trend model which takes into account chain indices of the dynamics of the investigated phenomena. Thanks to the use of such a model one can much earlier detect both favourable and unfavourable changes in the accident situation. The analyses made in this paper indicate that in the case of the chain indices of total accident rate dynamics the trend lines described by the linear function show a favourable general downward tendency whereas in the case of the chain indices of serious and fatal accident rate dynamics the trend lines described by the linear function show a very unfavourable general upward tendency in the investigated period.

3. The obtained values of the index of accident rate dynamics to construction production value dynamics indicate whether the trend of the two combined phenomena is downward or upward. If the changes show an upward trend, this signals that measures should be taken to improve the situation. As it has been demonstrated in this paper, the index of total, serious and fatal accident rate dynamics relative to construction production value dynamics shows a high variability in the investigated period. But the trend lines described by 1 st order polynomials show a marked unfavourable upward tendency. This means that the increments in the frequency of accidents are larger than the ones in the construction production value in the successive years of the investigated period.

The analyses presented here do not exhaust all the problems relating to accidents in the construction industry. The author sees a need to continue the investigation of the above problems, proposing the following directions for further research:

- an analysis of the accidents causes at work in construction and an estimation of their contribution to the number of accidents;

- an investigation of the contribution of failures and disasters which happened during construction work to the construction industry accident rate.

\section{References}

1. ABUDAYYEH, O.; FEDERICKS, T.; PALMQUIST, M.; TORRES, H. N. Analysis of occupational injuries and fatalities in electrical contracting industry. Journal of Construction Engineering and Management, 2003, 129(2), p. $152-158$.

2. CARTER, G.; SMITH, S. D. Safety hazard identification on construction projects. Journal of Construction Engineering and Management, 2006, 132(2), p. 197-205.

3. FANG, D.; CHEN, Y.; WONG, L. Safety climate in construction industry: a case study in Hong Kong. Journal of Construction Engineering and Management, 2006, 132(6), p. 573-584.

4. FREDERICKS, T.; ABUDAYYEH, O.; CHOI, S.; WIERSMA, M.; CHARLES, M. Occupational injuries and fatalities in the roofing contracting industry. Journal of Construction Engineering and Management, 2005, 131(11), p. 1233-1240.
5. HINZE, J.; DEVENPORT, J.; GIANG, G. Analysis of construction worker injuries that do not result in lost time. Journal of Construction Engineering and Management, 2006, 132(3), p. 321-326.

6. MOHAN, S.; ZECH, W. Characteristics of worker accidents on NYSOD construction project. Journal of Safety Research, 2005, 36(4), p. 353-360.

7. LEWANDOWSKI, J. Work safety management in company. Łódź: Łódź Polytechnic Publishers, 2000 (in Polish).

8. RUNKIEWICZ, L. On construction failures and disasters in Poland in years 1962-2004. Engineering and Building (Inżynieria i Budownictwo), 2006, 4, p. 193-195 (in Polish).

9. BEAVERS, J. E.; MOORE, J. R.; RINEHART, R.; SCHRIVER, W. Crane-related fatalities in the construction industry. Journal of Construction Engineering and Management, 2006, 132(9), p. 901-910.

10. HOŁA, B. Analysis of accident situation in Polish construction industry in period preceding accession to the European Union. Journal of Civil Engineering and Management, 2004, 10 (Suppl 2), p. 107-113.

11. SEELING, R. Possibilities of implementing the resolution No 92/57 ES of the Council of the EU ministries in Germany. Statyba (Civil Engineering), 2001, 7(4), p. 286293.

12. SUKYS, R. Perspectives and problems of health and safety in construction. Journal of Civil Engineering and Management, 2004, 10 (Suppl 1), p. 51-55 (in Lithuanian).

13. Statistical Office of the European Communities. Available from Internet: < epp.eurostat.ec.europa.eu.>.

14. Accidents at work in 1992-2005. GUS, Warsaw, 19932006.

15. KOWALSKI, J. Analysis of trends in accidents at work, occupational diseases and hazard in work environment during economic transformations. Occupational Safety (Bezpieczeństwo Pracy), 2001, 12, p. 14-17 (in Polish).

16. HOŁA, B. Model of development tendency of accident situation in construction industry. Archives of Civil Engineering, 2006, 52(1), p. 177-188.

17. HOŁA, B. Development tendency of accident situation in building construction. Archives of Civil and Mechanical Engineering, 2006, 6(3), p. 81-92.

18. KORADECKA, D. Work safety and ergonomics. Joint publication, CIOP, Warsaw, 1999 (in Polish).

19. STUDENSKI, R. Organization of safe work in company. Gliwice: Silesian Polytechnic Publishers, 1996 (in Polish).

20. GAMBATESE, J. A.; BEHM, M.; HINZE, J. Viability of designing for construction worker safety. Journal of Construction Engineering and Management, 2005, 131(9), p. 1029-1036.

21. HADIKUSUMO, B.; ROWLINSON, S. Integration of virtually real construction model and design-for-safetyprocess database. Automation in Construction, 2002, 11(5), p. 501-509.

22. MILCZAREK, M.; NAJMIEC, A. The relationship between workers safety culture and accidents, near accidents and health problems. International Journal of Occupational Safety and Ergonomics, 2004, 10(1), p. 25-33. 
23. MOHAMED, S. Safety climate in construction site environments. Journal of Construction Engineering and Management, 2002, 128(5), p. 375-384.

24. SIU, O.; PHILIPS, D. R.; LEUNG, T. Safety climate and safety performance among constructions workers in Hong Kong: the role of psychological strains as mediators. Accident Analysis Prevention, 2004, 36(3), p. 359-366.

25. ZELIAŚ, A. Statistical methods. Warsaw: Polskie Wydawnictwo Ekonomiczne, 2000 (in Polish).
26. ZIELIŃSKA, A., BECLA, A. Fundamentals of statistics and quantitative methods. Wrocław: I-Bis S.C., 2003 (in Polish).

27. KASSYK-ROKICKA, H. Statistics is not difficult. Warsaw: Państwowe wydawnictwo ekonomiczne, 1986 (in Polish).

28. OSTASIEWICZ, S. et al. Statistics - elements of theory and objective. Wrocław: Academy of Economics Publishers, 1999 (in Polish).

\section{NELAIMINGŲ ATSITIKIMŲ DAUGĖJIMO MODELIS STATYBŲ PRAMONĖJE}

\section{B. Hola}

\section{Santrauka}

Nelaimingų atsitikimų lygis tam tikrame nacionalinės ekonomikos sektoriuje yra ịvertinamas naudojantis tokia informacija: žmonių skaičiumi, įdarbintu analizuojamame sektoriuje, aukų skaičiumi dẻl nelaimingų atsitikimų darbe ir nelaimingų atsitikimų dažniu bei rimtumu. Ši informacija - tai statistinès charakteristikos. Jos informuoja apie nelaimingų atsitikimų lygi analizuojamu periodu, bet ne apie jo kitimą laike. Taip pat nelaimingus atsitikimus darbe lemia darbo tempas. Nelaimingų atsitikimų lygis ir produktyvumo apimtys keičiasi laikui bėgant. Labai svarbu nustatyti šiu dviejų dydžių kitimo laipsni. Dėl šios priežasties tiriant ṣ̌ fenomeną buvo išplètotas dinaminių pokyčių i̇vertinimo modelis. Be to, nelaimingų atsitikimu indeksų modelis rodo indeksus, kurie nustato statybų našumo ekonominį efektyvumą.

Reikšminiai žodžiai: nelaimingų atsitikimų lygis, statyba, nelaimingų atsitikimų indeksai, nelaimingų atsitikimų lygio modelis.

Bozena HOŁA. PhD, Eng, diploma obtained in civil engineering at Wrocław University of Technology, Poland, 1976. Working at WUT, Institute of Building Engineering, she has spent over 20 years in the field of research on modelling the construction processes, the managerial approach, safety and health protection at work. Member of PZITB. 